\title{
Primary extraskeletal osteosarcoma of small bowel mesentery presenting with acute bowel obstruction
}

\author{
Gabriel Yihan Tong ${ }^{1 \dagger^{*}}$, Kheng Song Leow ${ }^{2 \dagger}$, Sivaraj Gunasekaran ${ }^{3}$, Sivasubramanian Srinavasan $^{1}$, \\ Susan Swee-Shan Hue ${ }^{4}$ \\ 1. Department of Diagnostic Radiology, Khoo Teck Puat Hospital, Singapore \\ 2. Department of Radiology, Woodlands Health Campus, Singapore \\ 3. Department of Surgery, Khoo Teck Puat Hospital, Singapore \\ 4. Department of Pathology, National University Hospital, Singapore \\ These authors have contributed equally to the work and share the first authorship \\ *Corresponding author
* Correspondence: Dr Gabriel Yihan Tong, Department of Diagnostic Radiology, Khoo Teck Puat Hospital, 90 Yishun Central, 768828 Singapore
(入 gabriel.tong@mohh.com.sg) \\ Radiology Case. 2021 Dec; 15(12):10-19 :: DOI: 10.3941/jrcr.v15i12.4329
}

\begin{abstract}
Extraskeletal osteosarcoma of the small bowel mesentery is an exceedingly rare condition. It is an aggressive malignant neoplasm of mesenchymal origin characterized by osteoid formation. Final diagnosis is often made by histopathological analysis. However, we believe that prospective radiological diagnosis may be possible through careful analysis of densities (ossification) within the mesenteric mass. To the best of our knowledge, there is no current literature describing the radiological approach to making a prospective diagnosis of this condition. We present the 12th case of extraskeletal osteosarcoma worldwide and describe a radiological approach that is potentially useful in making a prospective diagnosis.
\end{abstract}

\section{CASE REPORT}

\section{CASE REPORT}

A 66-year-old female patient presented with 1-day history of colicky abdominal pain, associated with abdominal distension, vomiting and constipation. No hematochezia or melaena was reported. She had history of previous Caesarian section, diabetes mellitus and hyperlipidemia. There was no previous history of trauma, cancer or local radiotherapy to the abdomen. Physical examination showed abdominal distension with sluggish bowel sounds. Her blood pressure was elevated $(152 / 104 \mathrm{mmHg})$ with mild tachycardia (pulse rate of 101 beats per minute), possibly attributed to pain. She was afebrile
(36oC). Laboratory results showed mildly elevated white cell counts $14.8 \times 10^{\wedge} 9 / \mathrm{L}$ (normal range: $3.82-9.91 \times 10^{\wedge} 9 / \mathrm{L}$ ).

Abdominal radiograph revealed dilated small bowel loops consistent with small bowel obstruction. An opacity with "calcifications" was present in the left hemipelvis, raising the possibility of an underlying mass (Figure 1). Contrast-enhanced computed tomography (CECT) of the abdomen and pelvis confirmed the presence of a circumscribed soft tissue mass, centered in the small bowel mesentery, with associated hyperdensities (Figure 2a). The differential diagnoses of carcinoid tumor, sclerosing mesenteritis or gastrointestinal 
stromal tumor were proposed. Retrospectively, the hyperdensities are likely related to ossification (aka osteoid matrix) as they demonstrated CT attenuation of $1338 \mathrm{HU}$, similar to the attenuation of the bones (Figure 2b). Heterotopic ossification from previous Caesarean section was deemed less likely because the mass was separated from lower abdominal wall muscle (i.e. expected site of Caesarean section) and it did not show linear morphology of calcification (Figure $2 c-d$ ). The mass was surrounded by small bowel loops, with angulated interface suggestive of adhesion. The bowel wall enhancement was preserved. There was no evidence of bowel ischemia or perforation.

The patient underwent emergency laparotomy, adhesiolysis and en-bloc resection of the small bowel mesenteric mass as well as involved small bowel loops. Intraoperatively, the mass was centered at the small bowel mesentery, with adhesion to the adjacent bowel loops. Several peritoneal deposits were seen on the bowel serosa and mesentery, of which the largest nodule involving the sigmoid colon was excised. The resected specimen measured about 5 $\mathrm{cm}$, with pale to slightly yellowish appearance (Figure 3 ). Histopathological analysis showed high-grade malignant tumor at the mesentery / subserosa of the small bowel, comprising cellular fascicles, pattern-less arrangement of highly atypical spindled as well as polygonal / epithelioid cells with eosinophilic cytoplasm, vesicular nuclei and prominent nucleoli. Mitotic activity was brisk ( 30 mitoses per $10 \mathrm{HPF})$ (Figure 4a-c). Some areas of the tumor showed lace-like deposition of irregular woven bone that was intimately associated with malignant stromal cells and multinucleated giant cells. Immunohistochemically, the tumor cells were diffusely positive for SATB2, highly suggestive of osteoblastic differentiation and negative for other epithelial and mesenchymal markers (Figure 4d). Gastrointestinal stromal tumour was excluded based on negative CD117 and DOG1 expression.

The post-operative period was uneventful, and the patient was referred to the national specialist center for oncology, for consideration of adjuvant chemotherapy and radiotherapy.

\section{DISCUSSION}

\section{Etiology \& Demographics:}

Extraskeletal osteosarcoma (EOS) of the small bowel mesentery is an extremely rare neoplasm of mesenchymal origin with osteoid matrix formation, but no demonstrable attachment to an osseous structure[1]. It comprises of $1 \%$ of all soft tissue sarcomas and $4 \%$ of all osteosarcomas. EOS typically occurs in the lower extremities ( 47\%), upper extremities $(\sim 20 \%)$ and retroperitoneum $(\sim 17 \%)$, but very rarely in the small bowel mesentery[2]. Including the case presented here, there are a total of 12 cases of small bowel EOS reported worldwide (Table 3)[3-13].

The first case of primary EOS of mesentery was reported in 1956 by Fine \& Scout [3]. The condition typically affects patients between $6^{\text {th }}$ to $7^{\text {th }}$ decades of life, with about $2: 1$ male- to-female predominance[14]. The exact pathogenesis is unknown, but it is believed to be associated with previous trauma, local radiotherapy, myositis ossificans or malignant fibrous tissue disease[15].

\section{Clinical \& Imaging Findings}

The patients of EOS of small bowel mesentery usually present with progressively enhancing abdominal mass, pain, change in bowel habit or lower gastrointestinal bleeding $[8,12]$. Of the 12 cases worldwide, this is the first case of small bowel mesentery EOS presenting with acute bowel obstruction.

Radiographs are generally available and are useful in the evaluation of acute surgical abdomen, to detect bowel obstruction and/or pneumoperitoneum. In contrast-enhanced computed tomography (CECT), small bowel mesentery EOS classically appears as a "calcified" soft tissue mass centered at the small bowel mesentery.

The final diagnosis is often confirmed by histopathological and immunohistochemical analyses. The criteria for diagnosis of EOS include: (a) uniform morphological pattern of sarcomatous tissue that excludes the possibility of malignant mesenchymoma; (b) malignant osteoid formation by the sarcomatous tissue; and (c) definite exclusion of osseous origin[16]. The gross specimen of EOS can be variable surface can range from reddish-brown to yellowish and a tan gray, depending on the amount of necrosis and hemorrhage, but a pseudocapsule is usually present[1]. Microscopically, EOS is characterized by atypical spindle or polygonal (epithelioid) cells that produce abnormal osteoid or immature bone (that ranges from lacy network to coarse irregular trabecular pattern), allowing differentiation from malignant fibrous histiocytoma[2]. High grade pleomorphism and mitotic figures are present.

\section{Differential Diagnoses}

The common differential diagnoses of a calcified mesenteric mass include gastrointestinal carcinoid tumor, sclerosing mesenteritis, calcified metastatic disease and heterotopic mesenteric ossification (due to previous abdominal surgery or trauma).

\section{Gastrointestinal Carcinoid Tumor}

Gastrointestinal carcinoid tumors originate from neuroendocrine cells from the gastric or intestinal mucosa or submucosa[17]. They are rare entities, comprising $2 \%$ of all tumors of the gastrointestinal tract. They are often picked up incidentally on endoscopy or cross-sectional imaging[18]. Patients may be asymptomatic, or present with abdominal pain, gastrointestinal bleeding, bowel obstruction, and specific syndromes based on the various hormones and proteins produced. Double contrast radiography may show smooth intraluminal polypoid lesions or intramural masses[19]. CT findings include small enhancing masses in the mucosa or submucosa, with calcifications in up to $70 \%$. MRI often shows uniform bowel wall thickening or a nodular mass that is moderately low T1-weighted signal intensity, moderately high T2-weighted signal intensity, and moderate enhancement on post-contrast T1-weighted sequences[20]. 


\section{Sclerosing Mesenteritis}

Sclerosing mesenteritis is an uncommon disease described as a chronic inflammation and fibrosis of the mesenteric fat[21]. Prevalence is estimated to be $<1 \%$ [22]. Symptoms are nonspecific, and patients may present with abdominal pain, fever, weight loss, and diarrhea[21]. Barium studies may show displacement of bowel by a space occupying lesion in advanced disease[23]. CT findings are varied, ranging from faint increased attenuation in the small bowel mesentery or a soft tissue mass with "fat ring" sign of sparing of fat stranding around the mesenteric vessels. Calcifications may be seen in the necrotic areas[24]. MRI findings depend on the stage of disease, showing high T2-weighted signal intensity when edema is present during the panniculitis stage, or intermediate T1weighted and low $\mathrm{T} 2$-weighted signal intensities with delayed post-contrast enhancement during the retractile mesenteritis stage, when fibrosis is present[22].

\section{Calcified Metastatic Disease}

Several primary malignancies are classically known to develop calcifications, such as ovarian adenocarcinoma, mucinous colorectal adenocarcinoma, and malignant germ cell tumors[25]. These present in a variety of ways due to the wide range of conditions included. Abdominal radiographs may show calcific foci depending on extent of disease and calcification. CT and MRI findings are varied, with different malignancies demonstrating tendencies to develop calcified soft tissue masses in certain spaces; for example, peritoneal masses are seen in ovarian cancers, retroperitoneal masses are seen in germ cell tumors, and hepatic masses are seen in colorectal cancers[25].

\section{Heterotopic Mesenteric Ossification}

Heterotopic mesenteric ossification is also known as intraabdominal myositis ossificans[26]. It is a rare and benign condition, characterized by formation of ossificant pseudotumour at the base of the mesentery. The exact pathogenesis is unknown. However, it was postulated to be due to osteoblastic metaplasia of multipotent mesenchymal cells in response to inflammatory stimulus caused by previous abdominal trauma or surgery[26]. Heterotopic mesenteric ossification has a strong male predilection, often observed in middle aged-to-elderly men (mean age $\sim 61$ years). These men commonly present with signs and symptoms of bowel obstruction (abdominal pain, abdominal distension, nausea and vomiting). On radiograph and CT, radio-opacity is seen centered at the base of the mesentery. When trabecular architecture is seen, it is highly suggestive of ossification [27]. MRI findings are nonspecific. The classic histopathologic features include nodules of dense fibrous tissue in the mesentery, made up of well-formed lamellar bone trabeculae with dystrophic ossifications. The most important histological feature is zonal formation, characterized by progressive maturation of bone from the center to the periphery: central zone consists of immature hypercellular reactive fibrous tissue, middle zone consists of organized osteoid and peripheral zone consists of well-formed mature lamellar zone[27]. The prognosis is generally good with no evidence of malignant potential[26].

It is not surprising that extraskeletal osteosarcoma (EOS) of the small bowel mesentery is often overlooked. We believe that the EOS should be considered when the density within a mesenteric mass has a high CT attenuation of more than $700 \mathrm{HU}$, suggesting ossification (aka osteoid matrix). The CT attenuation of typical calcifications is usually about 100 to $400 \mathrm{HU}[28]$. In addition, careful analysis of such ossification may reveal a morphology similar to that of the bones (i.e. outer cortex and inner trabecular patterns). Such morphology may favor the diagnosis of EOS. Imaging function such as "edge enhancement / sharpening" may aid in the appreciation of such features. Evaluation of small bowel mesentery EOS using magnetic resonance imaging is usually nonspecific, with the lesion demonstrating intermediate T1-weighted signal intensity, high T2-weighted signal intensity and heterogeneous contrast enhancement [13].

\section{Treatment \& Prognosis}

Currently there is lack of consensus on the treatment of small bowel mesentery EOS due to the rarity of the condition and its poorly understood biological behaviors. In most of the published cases, the adopted treatments were extrapolated from management of other soft tissue sarcomas. A number of authors have suggested wide resection followed by adjuvant chemotherapy and radiotherapy[14,29]. Patients who received adjuvant chemotherapy (doxorubicin/ifosfamide) and radiotherapy are associated with lower recurrence, though there was no disease-specific survival benefit in multivariate analysis[30]. Tumor size of more than $5 \mathrm{~cm}$ is a predictor of poor prognosis[1]. Despite aggressive treatment, approximately one third of the patients develop local recurrence and distant metastasis[1,2]. The common sites of metastasis are lung $(>80 \%)$, followed by nodal and liver metastases[1,12]. The staging CT thorax of our patient showed no evidence of pulmonary metastasis. The overall prognosis of EOS is poor with 5-year survival ranging from $25 \%$ to $66 \%$ [15].

\section{TEACHING POINT}

Extraskeletal osteosarcoma of the small bowel mesentery is a rare condition that is easily overlooked in the differential diagnosis of a calcified mesenteric mass. Though the exact pathogenesis is unknown, this condition typically affects patients between 6 th to 7 th decades of life, with $2: 1$ male predilection. Prospective radiological diagnosis of this condition may be possible through careful analysis of densities (ossification) within the mesenteric mass.

\section{REFERENCES}

1. Bane BL, Evans HL, Ro JY, et al. Extraskeletal osteosarcoma. A clinicopathologic review of 26 cases. Cancer 1990;65:2762-70. PMID: 2160317

2. Chung EB, Enzinger FM. Extraskeletal osteosarcoma. Cancer 1987;60:1132-42. PMID: 3475157

3. Fine G, Stout AP. Osteogenic sarcoma of the extraskeletal soft tissues. Cancer 1956;9:1027-43. PMID: 13364888 
4. Shirazi PH, Rayudu GV, Fordham EW. Extraosseous osteogenic sarcoma of the small bowel demonstrated by $18 \mathrm{~F}$ scanning. J Nucl Med 1973;14:295-6. PMID: 4512317

5. Choudur HN, Munk PL, Nielson TO, Ryan AG-MJ. Primary mesenteric extraskeletal osteosarcoma in the pelvic cavity. Skeletal Radiol 2005;34:649-52. PMID: 15834564

6. Lee KH, Joo JK, Kim DY, Lee JS, Choi C, Lee JH. Mesenteric extraskeletal osteosarcoma with telangiectatic features: A case report. BMC Cancer 2007;7:82. PMID: 17504524

7. Heukamp LC, Knoblich A, Rausch E, et al. Extraosseous osteosarcoma arising from the small intestinal mesentery. Pathol Res Pract 2007;203:473-7. PMID: 17537587

8. Hussain MI, Al-Akeely MH, Alam MK, Jasser NA. Extraskeletal osteosarcoma, telangiectatic variant arising from the small bowel mesentery. Saudi Med J 2011;32:958-61. PMID: 21894362

9. Ahmed S, Calvin B, Garba E, Mohammed U, Shehu M. Primary mesenteric extraskeletal osteosarcoma. Niger J Basic Clin Sci 2013;10:95-7. PMID: None

10. Salim X, Paton D, Lambers A, Smith RC. First case of mesenteric extraosseous osteosarcoma in Australia. J Oncol Med \& Pract 2016;01:1-3. PMID: None

11. Oh SJ, Chang HK. Unusual giant cell-rich variant of extraskeletal osteosarcoma in the mesentery of small intestine. Int J Clin Exp Pathol 2017;10:11225-9. PMID: 31966474

12. Van den Broek NEJ, Willemsen P, Mattelaer C. A primary extraskeletal osteosarcoma of the mesentery: A case report. Acta Chir Belg 2018;118:125-8. PMID: 28434377

13. Ito S, Terado Y, Shimojima R, et al. Primary extraskeletal osteosarcoma of the mesentery: A case report. Int J Surg Case Rep 2019;60:111-4. PMID: 31212092

14. McCarter MD, Lewis JJ, Antonescu CR, Brennan MF. Extraskeletal osteosarcoma: analysis of outcome of a rare Neoplasm. Sarcoma 2000;4:119-23. PMID: 18521290

15. Lee JS, Fetsch JF, Wasdhal DA, Lee BP, Pritchard DJ, Nascimento AG. A review of 40 patients with extraskeletal osteosarcoma. Cancer 1995;76:2253-9. PMID: 8635029

16. Allan CJ, Soule EH. Osteogenic sarcoma of the somatic soft tissues. Clinicopathologic study of 26 cases and review of literature. Cancer 1971;27:1121-33. PMID: 5281245

17. Sheth S, Horton KM, Garland MR, Fishman EK. Mesenteric neoplasms: CT appearances of primary and secondary tumors and differential diagnosis. RadioGraphics 2003;23:457-73. PMID: 12640160

18. Wardlaw R, Smith JW. Gastric carcinoid tumors. Ochsner J 2008;8:191-6. PMID: 21603501
19. Levy AD, Sobin LH. Gastrointestinal carcinoids: Imaging features with clinicopathologic comparison. RadioGraphics 2007;27:237-57. PMID: 17235010

20. Bader TR, Semelka RC, Chiu VC, Armao DM, Woosley JT. MRI of carcinoid tumors: spectrum of appearances in the gastrointestinal tract and liver. J Magn Reson Imaging 2001;14:261-9. PMID: 11536403

21. Green MS, Chhabra R, Goyal H. Sclerosing mesenteritis: A comprehensive clinical review. Ann Transl Med 2018;6:336. PMID: 30306075

22. Apostolakis S, Ioannidis A, Tsioga G, Papageorgiou K, Velimezis G. A systematic investigation of sclerosing mesenteritis through CT and MRI. Radiol Case Rep 2016;11:299-302. PMID: 27920848

23. Ogden WW, Bradburn DM, Rives JD. Mesenteric Panniculitis: Review of 27 cases. Ann Surg 1965;161:864-75. PMID: 14295938

24. Horton KM, Lawler LP, Fishman EK. CT findings in sclerosing mesenteritis (panniculitis): Spectrum of disease. RadioGraphics 2003;23:1561-7. PMID: 14615565

25. Cheng JM, Tirumani SH, Kim KW, Saboo SS, Baez JC, Shinagare AB. Malignant abdominal rocks: where do they come from? Cancer Imaging 2013;13:527-39. PMID: 24334568

26. Ferreira C, Gomes C, Melo A et al. Heterotopic mesenteric and abdominal wall ossification - Two case reports in one institution. Int J Surg Case Rep. 2017;22-25. PMID: 28623757

27. Hakim M, McCarthy EF. Heterotopic mesenteric ossification. Am J Roentgenol. 2001;176:260-1. PMID: 11133585

28. Kwee RM, Kwee TC. Calcified or ossified benign soft tissue lesions that may simulate malignancy. Skeletal Radiol 2019;48:1875-90. PMID: 31297550

29. Longhi A, Bielack SS, Grimer R, et al. Extraskeletal osteosarcoma: A European Musculoskeletal Oncology Society study on 266 patients. Eur J Cancer 2017;74:9-16. PMID: 28167373

30. Fan Z, Patel S, Lewis VO, Guadagnolo BA, Lin PP. Should high-grade extraosseous osteosarcoma be treated with multimodality therapy like other soft tissue sarcomas? Clin Orthop Relat Res 2015;473:3604-11. PMID: 26197952 


\section{FIGURES}

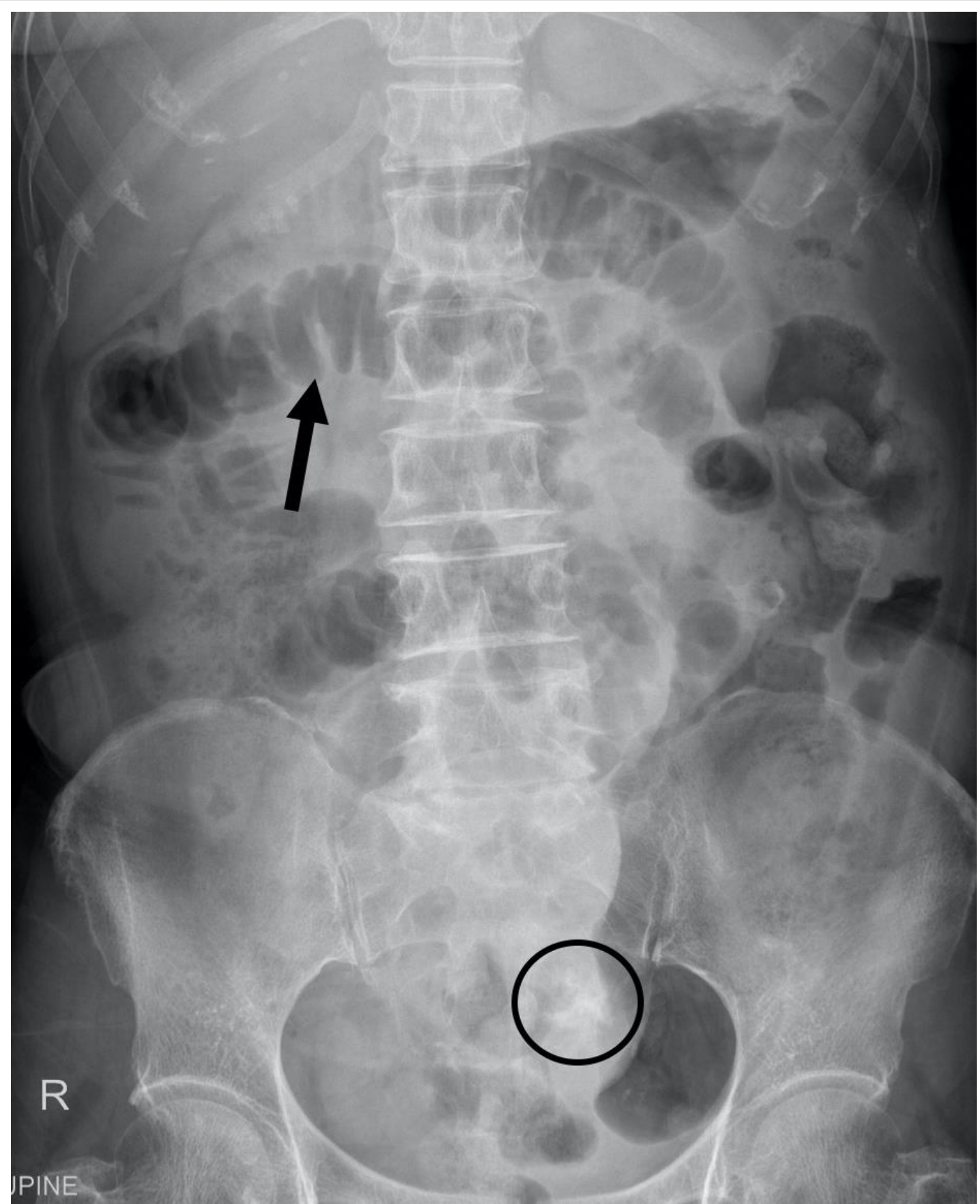

Figure 1: A 66-year-old female patient with extraskeletal osteosarcoma arising from the small bowel mesentery.

Findings: Abdominal radiograph shows dilated small bowel loops (arrow), suggestive of bowel obstruction. There is associated opacity with "calcifications" in the left hemipelvis (circle), suggestive of underlying mass.

Technique: Anteroposterior projection of abdominal radiograph; $73 \mathrm{kVp}$ x $16 \mathrm{mAs}$ 


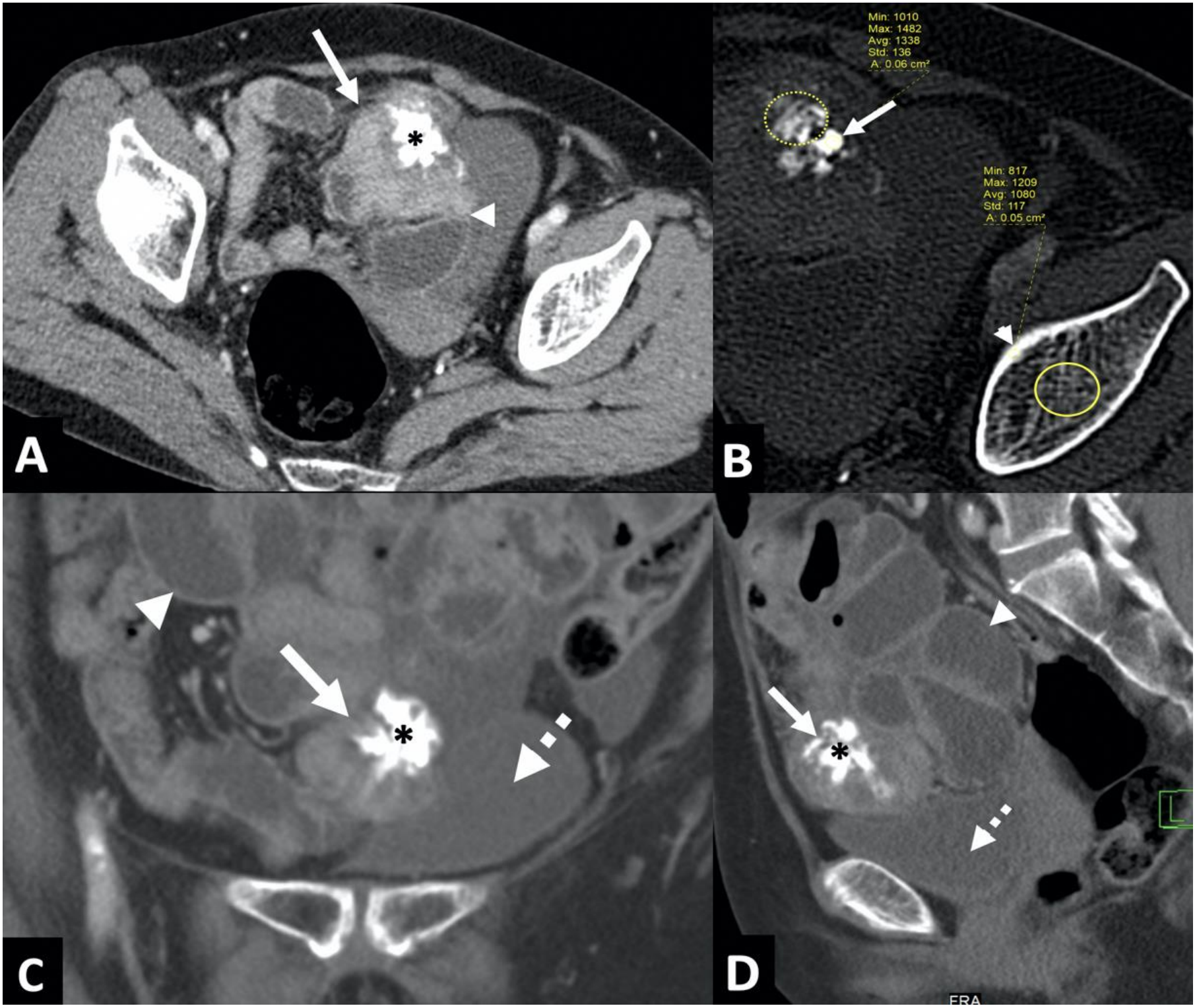

Figure 2: A 66-year-old female patient with extraskeletal osteosarcoma arising from the small bowel mesentery.

Findings:

(a) Axial section of contrast-enhanced computed tomography (CECT) shows a circumscribed soft tissue mesenteric mass (solid arrow) in the central lower abdomen, with associated central hyperdensities (asterisk). The angulated appearance of the adjacent small bowel loops (arrowhead) is suggestive of adhesion.

(b) The magnified view of the same axial CT image in bone window and edge enhancement function suggests that the central density is likely an ossification due to high CT attenuation of 1338HU (solid arrow). CT attenuation of $1080 \mathrm{HU}$ of the acetabular bone (arrowhead) for comparison. Part of the ossification (dotted circle) also shows a morphology similar to trabecular patterns of the left acetabular bone (solid circle).

(c, d) Coronal and sagittal reformatted CT images show that the mass (solid arrow) with central ossification (asterisk) is situated superior to the urinary bladder (dotted arrow). The mass is separated from the anterior abdominal wall, thus less likely to represent heterotopic ossification from previous Caesarean section. The adjacent bowel loops are dilated (arrowheads), consistent with bowel obstruction.

Technique: Multi-detector CT in portal venous phase following 60ml of intravenous Omnipaque 350 administration; Siemens SOMATOM Definition Flash, 3mm slice thickness; 100kVp x 144mAs. 


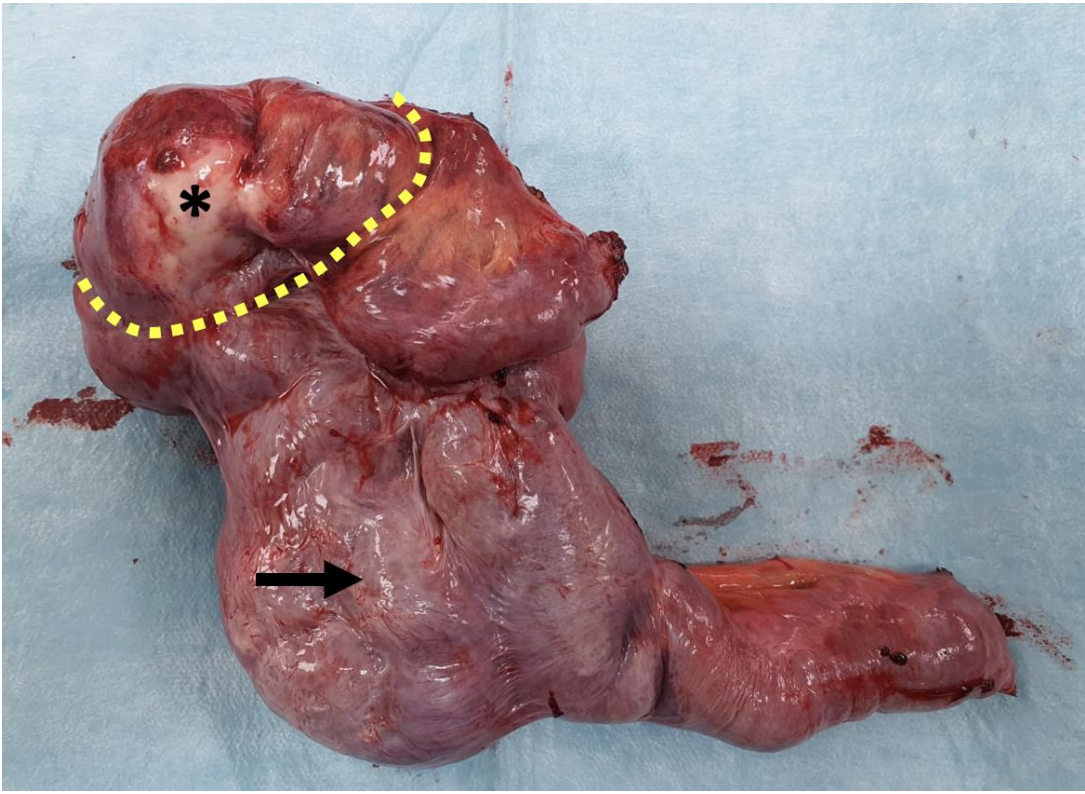

Figure 3: A 66-year-old female patient with extraskeletal osteosarcoma arising from the small bowel mesentery.

Findings: Intraoperative photograph of en-bloc resection of the mesenteric mass and adjacent bowel loops (arrow). The mass (asterisk) is pale-to-slightly yellowish appearance (indicated by dotted yellow line) and measures approximately $5 \mathrm{~cm}$ in size.

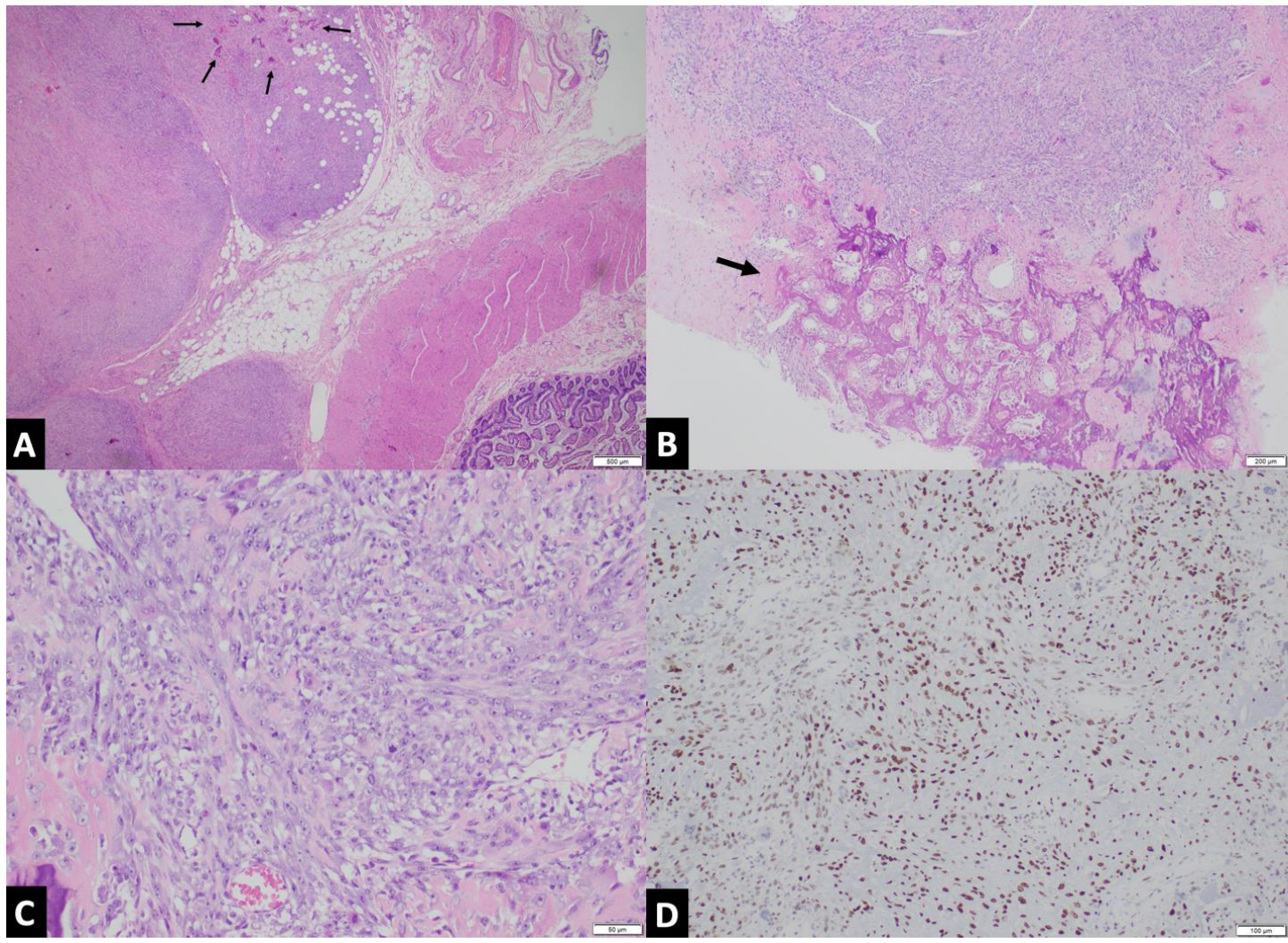

Figure 4: A 66-year-old female patient with extraskeletal osteosarcoma arising from the small bowel mesentery.

\section{Findings:}

(a) Histologic section shows a subserosal tumor with malignant bone deposition (arrows).

(b) Photomicrograph shows the tumor is composed of highly atypical spindled and epithelioid cells juxtaposed to malignant bone deposition (arrow).

(c) Histologic section shows the tumor is composed of highly atypical spindled and epithelioid cells with eosinophilic cytoplasm, vesicular nuclei and prominent nucleoli. Mitotic activity is brisk.

(d) Immunohistochemical findings: The tumor cells are diffusely positive for SATB2 (nuclear expression), confirming osteoblastic differentiation. 


\begin{tabular}{|c|c|}
\hline Etiology & $\begin{array}{l}\text { Exact etiology is unknown, although there are links to prior trauma, local radiotherapy, myositis ossificans, } \\
\text { or malignant fibrous tissue disease }\end{array}$ \\
\hline Incidence & Accounts for $\sim 1 \%$ of all soft tissue sarcomas, $\sim 4 \%$ of all osteosarcomas \\
\hline Gender Ratio & Slight increased male predilection, around 2:1 \\
\hline Age predilection & $6^{\text {th }}-7^{\text {th }}$ decade of life \\
\hline Risk factors & Prior trauma, local radiotherapy, myositis ossificans, malignant fibrous tissue disease \\
\hline Treatment & $\begin{array}{l}\text { - Lack of consensus due to rarity of the condition and poorly understood biological behaviors, but many } \\
\text { extrapolated from management of other soft tissue sarcoma } \\
\text { - Surgical resection } \\
\text { - +/- adjuvant chemoradiotherapy }\end{array}$ \\
\hline Prognosis & Poor 5-year survival between $25-66 \%$ \\
\hline Findings on imaging & $\begin{array}{l}\text { - CT: Mesenteric soft tissue mass with ossifications (>700HU), definite exclusion of osseous origin } \\
\text { - MRI: Non-specific. Intermediate T1-weighted signal intensity, high T2-weighted signal intensity and } \\
\text { heterogeneous contrast enhancement }\end{array}$ \\
\hline
\end{tabular}

Table 1: Summary table of extraskeletal Osteosarcoma.

\begin{tabular}{|c|c|c|c|c|}
\hline Diagnosis & \begin{tabular}{|l|} 
Clinical \\
Presentation
\end{tabular} & Radiograph Findings & CT Findings & MRI Findings \\
\hline $\begin{array}{l}\text { Mesenteric } \\
\text { Extraskeletal } \\
\text { Osteosarcoma }\end{array}$ & $\begin{array}{l}\text { Usually presents } \\
\text { with a slowly } \\
\text { enlarging mass } \\
\text { with pain }\end{array}$ & $\begin{array}{l}\text { May show } \\
\text { complications e.g., } \\
\text { bowel obstruction, } \\
\text { pneumoperitoneum }\end{array}$ & $\begin{array}{l}\text { Soft tissue mass with areas of } \\
\text { ossification (HU>700), } \\
\text { definite exclusion of osseous } \\
\text { origin }\end{array}$ & $\begin{array}{l}\text { Non-specific. Intermediate T1- } \\
\text { weighted signal intensity, high T2- } \\
\text { weighted signal intensity and } \\
\text { heterogeneous contrast enhancement }\end{array}$ \\
\hline $\begin{array}{l}\text { Gastrointestinal } \\
\text { Carcinoid } \\
\text { Tumor }\end{array}$ & $\begin{array}{l}\text { Asymptomatic, or } \\
\text { abdominal pain, } \\
\text { gastrointestinal } \\
\text { bleeding, bowel } \\
\text { obstruction, } \\
\text { specific } \\
\text { syndromes based } \\
\text { on } \\
\text { hormones/proteins } \\
\text { produced }\end{array}$ & $\begin{array}{l}\text { Double contrast } \\
\text { radiography may show } \\
\text { smooth masses located } \\
\text { in the gastric wall }\end{array}$ & $\begin{array}{l}\text { Small enhancing masses in } \\
\text { the mucosa or submucosa, } \\
\text { with calcifications in up to } \\
70 \%\end{array}$ & $\begin{array}{l}\text { Uniform bowel wall thickening, or a } \\
\text { nodular mass shows moderately low } \\
\text { T1-weighted signal intensity, } \\
\text { moderately high T2-weighteed } \\
\text { signal intensity, and moderately } \\
\text { enhancement on post-contrast } \\
\text { sequences }\end{array}$ \\
\hline $\begin{array}{l}\text { Sclerosing } \\
\text { Mesenteritis }\end{array}$ & $\begin{array}{l}\text { Non-specific, may } \\
\text { include abdominal } \\
\text { pain, fever, } \\
\text { weight loss, and } \\
\text { diarrhea }\end{array}$ & None & $\begin{array}{l}\text { Faint increased attenuation in } \\
\text { the small bowel mesentery or } \\
\text { a soft tissue mass with "fat } \\
\text { ring" sign of sparing of fat } \\
\text { stranding around the } \\
\text { mesenteric vessels. } \\
\text { Calcifications may be seen in } \\
\text { the necrotic areas }\end{array}$ & $\begin{array}{l}\text { Depends on the stage of disease; } \\
\text { high T2-weighted signal intensity } \\
\text { when edema is present during } \\
\text { panniculitis stage; intermediate T1- } \\
\text { weighted and low T2-weighted } \\
\text { signal intensities with delayed post- } \\
\text { contrast enhancement during } \\
\text { retractile mesenteritis stage }\end{array}$ \\
\hline $\begin{array}{l}\text { Calcified } \\
\text { Metastatic } \\
\text { Disease }\end{array}$ & $\begin{array}{l}\text { Various ways in } \\
\text { keeping with } \\
\text { primary } \\
\text { malignancy }\end{array}$ & $\begin{array}{l}\text { May show } \\
\text { calcifications depending } \\
\text { on extent of disease }\end{array}$ & $\begin{array}{l}\text { Soft tissue masses with areas } \\
\text { of calcifications, distributed } \\
\text { in locations specific to } \\
\text { primary malignancies }\end{array}$ & Similar to CT \\
\hline $\begin{array}{l}\text { Heterotopic } \\
\text { mesenteric } \\
\text { ossification }\end{array}$ & $\begin{array}{l}\text { Asymptomatic or } \\
\text { signs/symptoms } \\
\text { of bowel } \\
\text { obstruction }\end{array}$ & $\begin{array}{l}\text { Calcific opacity with } \\
\text { trabecular architecture }\end{array}$ & $\begin{array}{l}\text { Calcific density at the base of } \\
\text { mesentery with trabecular } \\
\text { architecture is highly } \\
\text { suggestive of the diagnosis }\end{array}$ & Similar to CT \\
\hline
\end{tabular}

Table 2: Differential diagnosis table for mesenteric extraskeletal Osteosarcoma. 


\begin{tabular}{|c|c|c|c|c|c|c|c|c|c|c|c|}
\hline & Author(s) & Year & Age & Sex & $\begin{array}{l}\text { Size } \\
(\mathrm{cm})\end{array}$ & $\begin{array}{l}\text { Presenting } \\
\text { complaint }\end{array}$ & $\begin{array}{l}\text { Histologic } \\
\text { Type }\end{array}$ & Surgery & \begin{tabular}{|l|} 
Adjuvant \\
Chemotherapy
\end{tabular} & Metastasis & Outcome \\
\hline 1 & Fine \& Stout [3] & 1956 & 39 & $M$ & - & - & - & - & - & $\begin{array}{l}\text { Mesenteric } \\
\text { lymph nodes }\end{array}$ & \begin{tabular}{|l|} 
Died 55 \\
days after \\
surgery
\end{tabular} \\
\hline 2 & Shirazi et al [4] & 1973 & 56 & $\mathrm{~F}$ & - & $\begin{array}{l}\text { Recurrent } \\
\text { abdominal mass, } \\
\text { weight loss, } \\
\text { appetite loss }\end{array}$ & - & Incomplete excision & None & Liver & $\begin{array}{l}\text { Died during } \\
\text { admission }\end{array}$ \\
\hline 3 & \begin{tabular}{|l} 
Choudur et al \\
{$[5]$}
\end{tabular} & 2005 & 45 & $M$ & 15 & Constipation & Osteoblastic & \begin{tabular}{|l|} 
Excision with small \\
bowel resection
\end{tabular} & $\begin{array}{l}\text { Doxorubicin, } \\
\text { cisplatin }\end{array}$ & None & - \\
\hline 4 & Lee et al [6] & 2007 & 67 & $\mathrm{M}$ & 15 & Abdominal pain & Telangiectatic & $\begin{array}{l}\text { En-bloc resection of } \\
\text { tumor \& segmental } \\
\text { colon \& } \\
\text { splenectomy }\end{array}$ & $\begin{array}{l}\text { Ifosfamide, } \\
\text { Adriamycin }\end{array}$ & Lung, liver & \begin{tabular}{|l} 
Died 4 \\
months after \\
surgery
\end{tabular} \\
\hline 5 & $\begin{array}{l}\text { Heukamp et al } \\
\text { [7] }\end{array}$ & 2007 & 61 & $\mathrm{M}$ & 20 & Abdominal pain & Osteoblastic & $\begin{array}{l}\text { Palliative tumor } \\
\text { resection after } \\
\text { chemotherapy } \\
\text { failed }\end{array}$ & \begin{tabular}{|l|} 
(non-adjuvant) \\
Doxorubicin, \\
cisplatin, \\
cyclophosphami \\
de, ifosfamide \\
\end{tabular} & - & $\begin{array}{l}\text { Died } 2 \\
\text { weeks after } \\
\text { surgery; } 10 \\
\text { months after } \\
\text { diagnosis } \\
\end{array}$ \\
\hline 6 & Hussain et al [8] & 2011 & 40 & $\mathrm{M}$ & 13 & $\begin{array}{l}\text { Lower } \\
\text { gastrointestinal } \\
\text { bleed }\end{array}$ & Telangiectatic & $\begin{array}{l}\text { Palliative en-bloc } \\
\text { resection of tumor } \\
\& \text { small bowel, } \\
\text { hepatic metastasis } \\
\text { resection }\end{array}$ & $\begin{array}{l}\text { Yes, regimen } \\
\text { not known }\end{array}$ & $\begin{array}{l}\text { Liver, } \\
\text { duodenum, } \\
\text { peritoneal } \\
\text { recurrence }\end{array}$ & $\begin{array}{l}\text { Followed up } \\
\text { for } 14 \\
\text { months }\end{array}$ \\
\hline 7 & Ahmed et al [9] & 2013 & 56 & $\mathrm{M}$ & - & $\begin{array}{l}\text { Lower abdominal } \\
\text { pain, hematochezia }\end{array}$ & Osteoblastic & $\begin{array}{l}\text { Tumor excision } \\
\text { with ileal resection }\end{array}$ & No & - & $\begin{array}{l}\text { Lost to } \\
\text { follow up }\end{array}$ \\
\hline 8 & Salim et al [10] & 2016 & 63 & $\mathrm{M}$ & 15 & $\begin{array}{l}\text { Abdominal pain, } \\
\text { loose stools }\end{array}$ & - & $\begin{array}{l}\text { En-bloc resection of } \\
\text { tumor \& adherent } \\
\text { small bowel }\end{array}$ & Adriamycin & $\begin{array}{l}\text { Peritoneal } \\
\text { recurrence }\end{array}$ & $\begin{array}{l}\text { Died 18 } \\
\text { months later }\end{array}$ \\
\hline 9 & $\begin{array}{l}\text { Oh \& Chang } \\
{[11]}\end{array}$ & 2017 & 70 & $\mathrm{~F}$ & 15 & $\begin{array}{l}\text { Abdominal pain, } \\
\text { mass }\end{array}$ & Giant-cell rich & $\begin{array}{l}\text { En-bloc resection of } \\
\text { tumor \& small } \\
\text { intestine }\end{array}$ & No & No & $\begin{array}{l}\text { Died 2 } \\
\text { months later }\end{array}$ \\
\hline $\mathbf{1 0}$ & $\begin{array}{l}\text { Van den Broek } \\
\text { et. al [12] }\end{array}$ & 2017 & 71 & $\mathrm{~F}$ & 14 & $\begin{array}{l}\text { Incomplete } \\
\text { defecation }\end{array}$ & Osteoblastic & $\begin{array}{l}\text { En-bloc resection of } \\
\text { tumor \& sigmoid, } \\
\text { left ovary, fallopian } \\
\text { tube, ureter part }\end{array}$ & No & $\begin{array}{l}\text { Peritoneal } \\
\text { recurrence }\end{array}$ & $\begin{array}{l}\text { Alive with } \\
\text { recurrence }\end{array}$ \\
\hline 11 & Ito et. al [13] & 2019 & 46 & $F$ & 3.8 & $\begin{array}{l}\text { Incidental finding } \\
\text { on abdominal US }\end{array}$ & - & $\begin{array}{l}\text { Laparoscopic } \\
\text { resection }\end{array}$ & No & None & \begin{tabular}{|l} 
Alive 10 \\
months after \\
surgery
\end{tabular} \\
\hline 12 & $\begin{array}{l}\text { Case in this } \\
\text { report }\end{array}$ & 2021 & 66 & $\mathrm{~F}$ & $\sim 5$ & Bowel obstruction & Osteoblastic & \begin{tabular}{|l|} 
En-bloc resection of \\
tumor \& small \\
bowel loop \& \\
peritoneal nodule \\
resection
\end{tabular} & Not available & \begin{tabular}{|l|} 
Peritoneal \\
deposits on \\
first \\
presentation
\end{tabular} & $\begin{array}{l}\text { Alive } 6 \\
\text { months after } \\
\text { surgery } \\
\text { (time of this } \\
\text { report) }\end{array}$ \\
\hline
\end{tabular}

Table 3: Literature review of extraskeletal Osteosarcoma of small bowel mesentery. 


\section{ABBREVIATIONS}

CECT $=$ Contrast-enhanced Computed Tomography

EOS $=$ Extraskeletal Osteosarcoma

MRI = Magnetic Resonance Imaging

\section{KEYWORDS}

Extraskeletal osteosarcoma; Mesentery; Ossification; Sarcoma; Soft tissue neoplasms

\section{ACKNOWLEDGEMENTS}

The authors would like to thank Professor Wilfred Peh, FRCP, FRCR (from Department of Diagnostic Radiology, Khoo Teck Puat Hospital, Singapore) and Dr Lim Tze Chwan, MBBS, MMed, FRCR, FAMS (from Department of Radiology, Woodlands Health Campus, Singapore) for their guidance. The authors would also like to thank Dr Vijayadwaja Desai, MBBS, MRCPath (from Department of Diagnostic Radiology, Khoo Teck Puat Hospital, Singapore) for his assistance in obtaining some of the histopathological images.

\section{Online access}

This publication is online available at:

www.radiologycases.com/index.php/radiologycases/article/view/4329

\section{Peer discussion}

Discuss this manuscript in our protected discussion forum at: www.radiolopolis.com/forums/JRCR

\section{Interactivity}

This publication is available as an interactive article with scroll, window/level, magnify and more features.

Available online at www.RadiologyCases.com

\section{Published by EduRad}

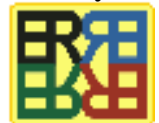

www.EduRad.org 